\title{
Calendar of Events
}

March 25-29, 1985. A Conference on Neuroradiology will be held at the Snowmass Club, Snowmass, Colorado. Contact: Ms. Janice Ford, CME Coordinator, Department of Radiology, Hospital of the University of Pennsylvania, 3400 Spruce Street, Philadelphia, PA 19104. (215-662-6904).

April 24-26, 1985. International Symposium on Peptides and Ion Transport will be held in Florence, Italy. Contact: Peptides and Ion Transport, c/o Fondazione Giovanni Lorenzini, Via Monte Napoleone, 23, 20121 Milan, Italy.

May 9-10, 1985. Huntington's Disease - An Approach to Care: Interdisciplinary Strategies for Maximizing Quality of Life conference will be held in Toronto, Ontario. Contact: The Huntington Society of Canada, Box 33, Cambridge, Ontario, Canada MIR 5T8.

June 9-11, 1985. VIII International Symposium on Parkinson's Disease will be held in New York City. Contact: Assistant Secretary General, Kenneth J. Bergman, M.D., Department of Neurology, Mount Sinai School of Medicine of the City University of New York, New York, N.Y. 10029 U.S.A.

June 21-25, 1985. Fifth International Single-Fibre EMG Course and Symposium, Toronto, Ontario. Contact: Vera Bril, M.D., EN 11-211, Toronto General Hospital, Toronto, Ontario, Canada M5G 1L7. (416) 595-3315.

June 24-25, 1985. The Fifth Annual International Conference on CT and MRI of the Head and Spine will be held at Chateau La Napoule, France. Contact: Ms. Janice Ford, CMEM Coordinator, Department of Radiology, Hospital of the University of Pennsylvania, 3400 Spruce Street, Philadelphia, PA 19104. (215-662-6904).

June 25-28, 1985. XX Canadian Congress of Neurological Sciences will be held in Montreal, Quebec. Deadline for abstracts is February 15, 1985. Contact Dr. Serge Gauthier, Montreal
Neurological Institute, 3801 University Street, Montreal, Quebec H3A 2 B4.

July 4-7, 1985. IX Meeting of the World Society for Stereotactic and Functional Neurosurgery will be held in Toronto, Ontario. The deadline for submission of abstracts is September 1, 1984. Contact: Dr. R.R. Tasker, EN 7-221, Toronto General Hospital, 101 College Street, Toronto, Ontario M5G 1 L7.

July 7-13, 1985. The 8th International Congress of Neurological Surgery will be held in Toronto, Ontario. Contact: Alan R. Hudson, 8th International Congress President, Division of Neurosurgery, 38 Shuter Street, Toronto, Ontario, Canada M5B 1 A6.

July 7-13, 1985. World Federation of Neurosurgical Nurses will be held in Toronto, Ontario. Contact: Elizabeth Noroian, 571 S. Braddock Avenue, Pittsburgh, PA 15221, U.S.A.

July 14-17, 1985. International Society for Pediatric Neurosurgery meeting will be held in Mexico City, Mexico. Contact: Dr. Fernando Rueda Franco, Instituto Nacional de Pediatria, Servicio de Neurocirugia, Insurgentes Sur 3700, Mexico, D.F. 04530, Mexico.

August 1985. 13th International Congress of Biochemistry. Amsterdam, The Netherlands.

September 4, 1985. The XIIth International Symposium of the "Fulton Society on Brain Mechanisms of Emotions" will be held in Hamburg, Federal Republic of Germany along with the XIIIth World Congress of Neurology. Contact: Prof. Dr. Victor Soriano, Calle Buenos Aires 363, Montevideo, Uruguay.

September 18-20, 1985. Update Course on Cerebral Vascular Disease will be held at University Hospital, London, Ontario, Canada. Contact: Dr. V.C. Hachinski, Room 1-3, University Hospital, P.O. Box 5339, Station A, London, Ontario, Canada N6A 5A5.

\begin{tabular}{|l|}
\hline \\
ADVERTISER'S INDEX \\
Ciba Geigy \\
Lioresol - OBC \\
Tegretol - vi, vii, xiii \\
Dantec Electronics Ltd. \\
Evomatic - viii \\
Neuromatic - X \\
Sandoz Canada Inc. \\
Cafergot - IBC \\
Fiorinal - xii \\
Parlodel - IFC, ii, iii, iv \\
Unimed \\
Serc - ix \\
\hline
\end{tabular}

